\title{
FUNGSI KONTRAK DAGANG DALAM TRANSAKSI EKSPOR IMPOR
}

\author{
Oleh : Abdillah Sani
}

ABSTRACT

Kegiatan perdagangan luar negeri yang lazim disebut ekspor impor dalam era globalisasi sekarang ini sudah sedemikian terbuka lebar dan membuka kesempatan bisnis yang luas kepada para Usahawan Kecil dan Menengah (UKM) yang potensial, untuk memasuki pasar berbagai Negara. Sejalan dengan globalisasi ini, Negara-negara yang menjadi tujuan ekspor cenderung menjadi lebih protektif karena khawatir pintu yang terlalu dibuka lebar akan menyebabkan banjirnya barang impor sehingga berpotensi mematikan produk-produk dalam negeri. Berbagai persyaratan pun bermunculan dengan dalih melindungi produsen dalam negeri, untuk membatasi masuknya barang-barang ekspor dari berbagai Negara. Meskipun demikian, kegiatan ekspor impor antar negara sejauh ini, terus berkembang dan mengalami percepatan. Oleh karena itu keberadaan kontrak dagang sebagai dokumen tertulis yang mengikat dan menjamin kepentingan kedua belah pihak menjadi sangat penting. Dalam kontrak dagang ekspor ini lah para eksportir dan importir membuktian komitmennya untuk bertransaksi secara jujur dan saling menguntungkan. Pengetahuan para pihak tentang apa isi dan bagaimana kontrak dagang ekspor yang tertuang dalam tulisan ini diharapkan bisa menjadi pembuka wawasan untuk eksportir dan importir menyusun suatu bentuk perjanjian dagang yang melindungi kepentingan mereka saat berhadapan dengan mitra luar negerinya.

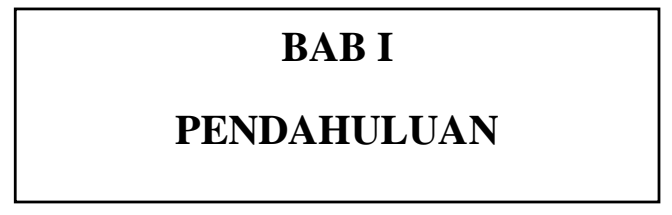

\section{A. Latar Belakang}

Kegiatan ekspor impor merupakan pertukaran barang dan jasa melewati batas kepabeanan suatu negara, yang terjadi akibat kebutuhan yang tidak bisa dipenuhi di dalam negri, sehingga harus diperoleh dari negara lain. Perdagangan lintas negara batas berbeda dengan perdagangan dalam negeri, ditandai oleh banyaknya perbedaan antara kedua negara dari mana para pelaku perdagangan berasal, seperti perbedaan dalam peraturan kepabeanan, perbedaan standard mutu produk, perbedaan standard ukuran takaran dan timbangan serta peraturan perdagangan luar negeri yang ditetapkan oleh pemerintah setempat (Amir M.S,2003:100). Selain hal-hal tersebut masih banyak terdapat perbedaan lain, misalnya perbedaan bahasa, mata uang yang digunakan, nilai mata uang, budaya, serta perbedaan sistem hukum yang berlaku di masingmasing negara.

Kegiatan ekspor impor mempunyai nilai ekonomi yang sangat penting, baik bagi perkembangan kegiatan ekonomi para pelakunya sendiri, maupun bagi masyarakat serta pemerintah. Manfaat yang diperoleh dari perdagangan interperekomian nasional. Peningkatan ekspor akan mendorong pertumbuhan ekonomi dan pendapatan nasional negara dan menambah cadangan devisa negara.

Bagi masyarakat, pertumbuhan ekspor akan dapat meningkatkan kesejahteraan dan berkurangnya tingkat pengangguran karena didorong oleh terjadinya peningkatan produktivitas guna memenuhi permintaan pembeli luar negeri.

Seiring dengan semakin meningkatnya intensitas ekspor impor yang diakukan oleh para pengusaha dan sejalan dengan target yang ditetapkan oleh Pemerintah untuk meningkatkan prosentase penerimaan negara dari hasil ekspor sebesar $300 \%$ pada akhir masa pemerintahan 
Presiden Joko Widodo pada tahun 2019, berbagai hal yang menyangkut aktivitas ekspor impor terus dibenahi. Regulasi ekspor harus terus disederhanakan dan makin transparan, peningkatan fasilitasi yang mendukung pengusaha, serta para pelaku ekspor impor yang harus diberikan pembinaan secara integratif dan berkesinambungan agar makin tangguh dalam memanfaatkan setiap peluang yang muncul dari pasar bebas, baik dalam kerangka Masyarakat Ekonomi Asean (MEA), AFTA, APEC, WTO maupun perjanjian bilateral dan internasional lainnya.

Hubungan dagang maupun diplomatik antara Indonesia dengan negara- negara yang menjadi tujuan ekspor (NTE) juga harus makin meluas, bukan hanya dengan negara-negara tujuan ekspor tradisional seperti USA, negara-negara Eropa dan Jepang, tetapi juga harus meluas ke negara-negara tujuan ekspor non tradisional seperti negara-negara Asean, Asia Pasifik, Amerika Latin maupun negara-negara di semenanjung Afrika.

Transaksi ekspor maupun impor, biasanya diawali dengan kegiatan korespondensi, yakni surat menyurat antara seller dan buyer, sisanya melalui negosiasi tatap muka atau secara lisan via telpon. Baru setelah tercapai pointpoint kesepakatan antara kedua belah pihak, akan diteruskan dengan menuangkan kesepakatan tersebut dalam bentuk dokumen tertulis yang disebut kontrak dagang ekspor. Kontrak dagang yang dipilih bisa yang bentuknya sederhana seperti "minutes" atau notulen yang ditandatangani bersama, dalam bentuk "Memorandum of Understanding" (MOU) atau Nota Kesepahaman bersama, maupun Kontrak Dagang
Ekspor yang sifatnya lebih kompleks dan lengkap.

Penuangan kesepakatan bersama ini lazim disebut dengan "Persetujuan Prinsip" antara kedua belah pihak, yang selanjutnya akan menjadi landasan bagi kedua belah untuk merealisasi ekspor, menjadi landasan pemenuhan hak dan kewajiban mereka, maupun menjadi dasar jika kelak antara mereka timbul kejadian-kejadian yang tidak diharapkan seperti wanprestasi maupun sengketa dagang lain.

Berdasarkan uraian di atas, pemahaman para pelaku perdagangan ekspor maupun impor atas prinsip-prinsip yang terdapat dalam penyusunan Kontrak Dagang Ekspor menjadi keniscayaan, guna mencegah timbulnya kerugian dalam aktivitas bisnis mereka. Dalam kaitan ini lah Penulis memandang perlu untuk menyusun sebuah tulisan dengan judul : FUNGSI KONTRAK DAGANG DALAM TRANKSAKSI EKSPOR IMPOR, yang Penulis harapkan akan bermanfaat baik sebagai acuan bagi Penulis sendiri maupun sebagai sumbangsih kepada masyarakat luas yang ingin mengetahui tentang seluk beluk kontrak dagang ekspor impor.

\section{B. Identifikasi Masalah}

Setelah menjelaskan latar belakang mengapa Penulis ingin menyusun tulisan tentang kontrak dagang ekspor ini, beberapa hal akan menjadi acuan pembahasan, yakni :

1. Fungsi kontrak dagang dalam kegiatan eksor impor dan elemenelmen yang harus dicermati

2. Cara menyusun kontrak dagang ekspor impor yang sederhana. 


\section{Perumusan Masalah}

Semua hal tadi Penulis rumuskan menjadi permasalahan tulisan sebagai berikut:

1. Apa fungsi kontrak dagang dalam kegiatan eksor impor dan apa saja elemen-elmen yang harus dicermati?

2. Bagaimana cara menyusun kontrak dagang ekspor impor yang sederhana?

\section{Tujuan Penulisan}

1. Sebagai bahan ajar bagi Penulis dalam menyajikan materi kontrak dagang ekspor impor kepada para peserta pelatihan ekspor impor

2. Untuk memberikan pemahaman tentang fungsi kontrak dagang ekspor impor bagi para pembaca

3. Memberi penjelasan kepada pembaca tentang cara menyusun kontrak dagang ekspor impor yang sederhana agar dapat memberikan manfaat jika pembaca terlibat dalam transaksi ekspor impor.

\section{BAB II}

\section{KERANGKA TEORITIK}

\section{A. Kajian kepustakaan}

Perdagangan ekspor-impor lazim juga disebut sebagai perdagangan dokumen karena hampir seluruh aktivitasnya dibuktikan atau direpresentasikan dalam bentuk dokumen. Penawaran dilakukan dalam bentuk terulis berupa surat perkenalan (introduction letter) yang dikirim oleh seorang eksportir kepada calon pembelinya di luar negeri. Jika si calon pembeli tertarik terhadap apa yang ditawarkan, dia akan mengirim pesanan juga secara tertulis. Surat balasan yang sering disebut inquiry ini bisa berisi permintaan penjelasan informasi lebih lanjut, atau bisa pula permintaan agar dikirimkan barang contoh, brosur, daftar harga dan sebagainya.

Korespondensi antara kedua belah pihak akan terus berlanjut hingga tercapai kesepakatan-kesepakatan tertentu yang mengarah kepada suatu transaksi. Jika kedua belah pihak merasa perlu untuk mengikatkan diri dalam bentuk dokumen tertulis yang menyebutkan secara jelas hak dan kewajiban masing-masing pihak, dokumen inilah yang disebut kontrak dagang ekspor impor.

Dengan demikian, kontrak dagang ekspor ini akan berfungsi sevbagai dasar hukum bagi kedua belah pihak dalam merealisasi hak dan kewajiban masing-masing, sesuai dengan kaedah dalam ilmu hukum yang menyebutkan bahwa : "perjanjian adalah hukum bagi mereka yang membuatnya". Dengan demikian, ada kepastian yang mengikat kedua belah pihak, dimana mereka akan terkena ancaman hukuman jika melalaikan apa yang dituangkan dalam kontrak tersebut. Selain itu, kedua belah pihak juga akan mendapat perlindungan hukum jika haknya tidak terpenuhi.

Untuk lebih jelasnya bagaimana suatu kontrak dagang menjadi alat pemaksa dalam realisasi transaksi ekspor, kiranya akan lebih baik jika terlebih dahulu kita memahami bagaimana sebenarnya proses yang berjalan sejak awal sampai tercapainya pemenuhan hak dan kewajiban kedua belah pihak. 
Secara sederhana, proses tersebut dapat ditelusuri dalam bagan prosedur ekspor impor sebagaimana tertera di bawah ini, meskipun mungkin dalam realisasinya tentu proses tersebut tidaklah sesederhana itu, tapi paling tidak bagan ini sudah memberikan pemahaman sederhana, tentang bagaimana jalannya suatu proses ekspor impor.
Atase Perdagangan RI di Kedutaan Besar RI atau pejabat Indonesia Trade Promotion Center di luar negeri, Atase Perdagangan asing di kedutaan besar asing yang ada di Jakarta, Kamar Dagang dan Industri negara asing di Jakarta dan kota-kota besar lainnya di Indonesia, ataupun melalui lembagalembaga perdagangan asing di

PROSEDUR EKSPOR

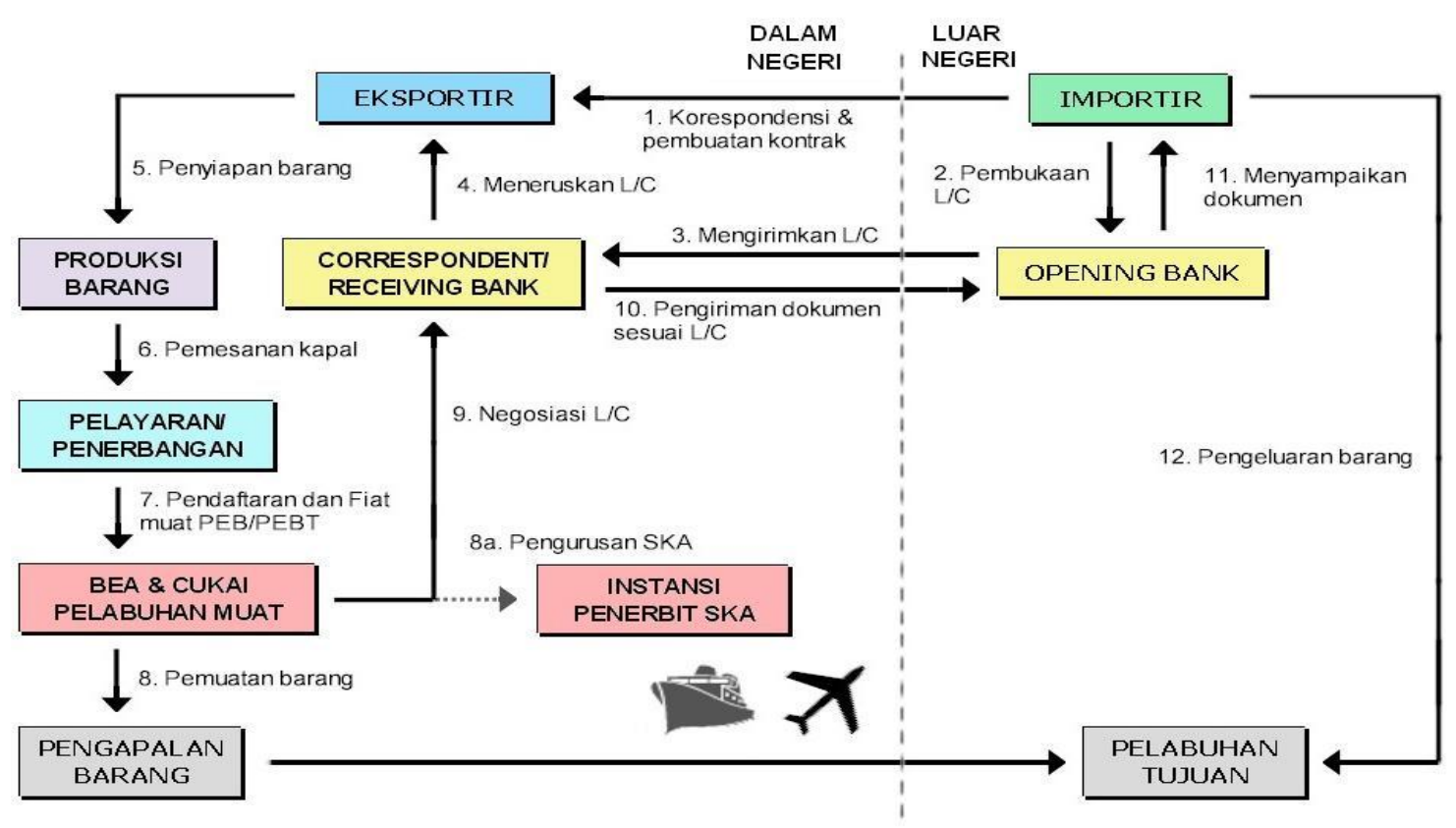

\section{Penjelasan:}

\section{a. Proses awal hingga penandatangan kontrak dagang ekspor}

1) Eksportir mempromosikan produk yang akan diekspor melalui berbagai macam media promosi seperti pameran dagang, iklan di koran, majalah, radio, searching di internet, maupun cara-cara lain, baik di dalam negeri maupun di luar negeri, seperti mendatangi badan-badan khusus urusan promosi ekspor seperti Direktorat Jeenderal Pengembangan Ekspor Nasional (DJPEN), Dewan Penunjang Ekspor (DPE), Kamar Dagang dan Industri Indonesia (Kadin Indonesia),
Indonesia. seperti American Chamber of Commerce (AMCHAM), China External Trade Association (CETRA), Japan External Trade Organization (JETRO), Korean Trade Agency (KOTRA) dan lain-lain. Tujuan promosi adalah untuk memperkenalkan produk dan perusahaan kepada calon pembeli serta menarik minat calon importir terhadap komoditas yang akan diekspor.

2) Importir atau calon pembeli yang berminat kemudian akan mengirimkan surat permintaan harga atau Letter of Inquiry kepada eksportir yang mengirim letter of introduction, yang lazimnya berisikan permintaan penawaran harga dengan 
memberitahukan berbagai informasi seputar produk yang ditawarkan seperti tentang mutu, spesiifikasi, jumlah yang bisa dipesan, harga satuan dan total harga dalam valuta asing (US\$ atau lainnya), waktu pengiriman (shipment date), dan nama pelabuhan tujuan yang diinginkan.

3) Eksportir memenuhi permintaan importir dengan mengirimkan surat penawaran harga yang lazim disebut dengan Offersheet. Offersheet berisikan keterangan sesuai permintaan importir, seperti uraian barang, mutu, jumlah, waktu penyerahan, harga dan tempat penyerahan barang, syarat pembayaran, waktu pengapalan, cara pengepakan barang, brosur, dan bila perlu contoh barang yang ditawarkan. Penawaran itu juga menyebutkan apakah penawaran bersifat free offer ataukah firm offer.

4) Importir, setelah mempelajari offer sheet dari eksportir, menempatkan surat pesanan dalam bentuk ordersheet atau purchase order kepada eksportir.

5) Setelah melakukan tatap muka melalui negosiasi langsung atau melalui media lain seperti email ataupun telepon antara kedua belah pihak, eksportir menyiapkan konsep kontrak jual beli ekspor ( Export sale contract. sesuai dengan data dari offersheet dan ordersheet ditambah dengan keterangan seperti force majeur clause, klaim, syarat pengapalan seperti shipment, transshipment, dan lain-lain.

Hal penting yang juga harus disepakati oleh kedua belah pihak adalah tentang pengaturan pertanggungjawaban selama perjalanan barang. Siapa yang harus menanggung biaya transporasi, masalah resiko, pembayaran asuransi, yang mengacu kepada ketentuan-ketentuan yang dimuat dalam International Commercial Terminologies (INCOTERMS) yang versi terakhirnya dibuat pada tahun 2010 . Incoterms inilah yang harus disepakati oleh eksporter dan importer, hal mana juga akan diperhitungkan dalam besarnya pembayaran yang akan dilakukan. Siapa pihak yang akan menanggung pembiayaan transporasi, bea-bea dan asuransi bisa dilihat dalam tabel Incoterms berikut ini:

6) Setelah kontrak tersebut ditandatangani oleh eksportir, maka kontrak itu akan dikirimkan kepada importir untuk ditandatangani pula sebagai tanda persetujuan atas sale's

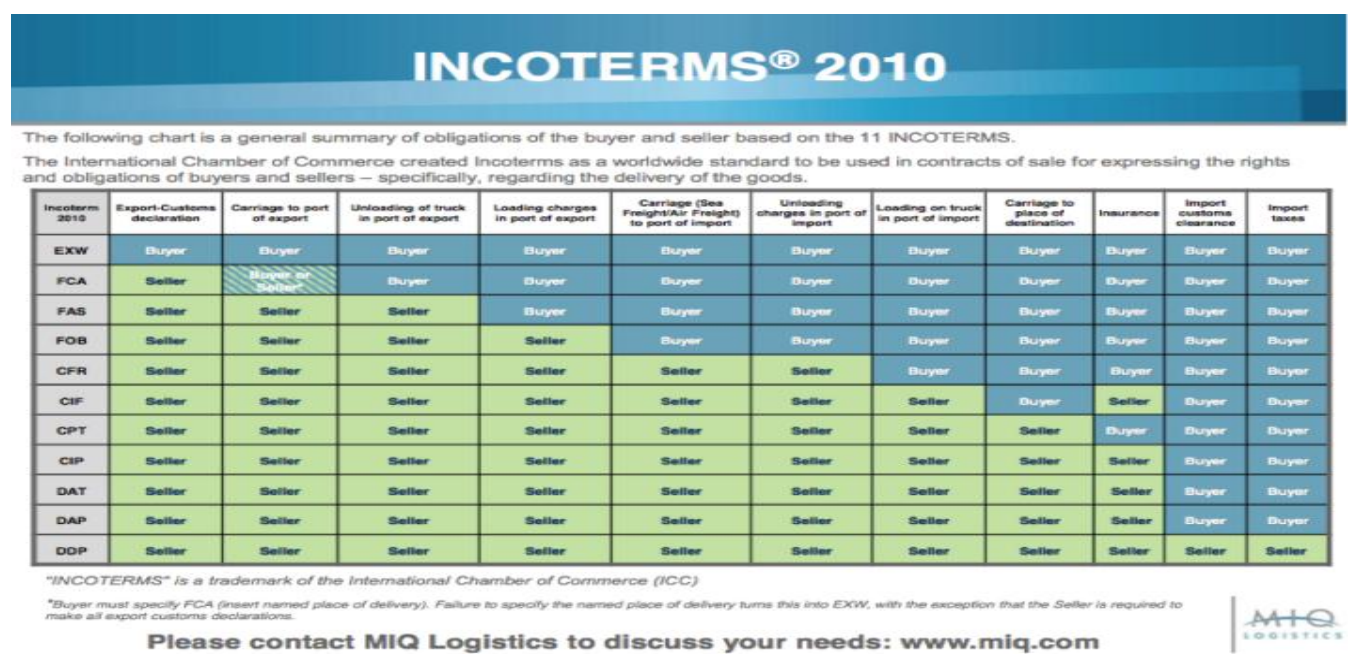


contract itu. Lazimnya Export sale contract dibuatkan aslinya dalam rangkap dua (two original). Kontrak juga bisa dikonsep oleh pihak importir dan dikirim kepada eksportir. Siapa yang akan membuat konsep kontrak dagang dimaksud, adalah sesuai kesepakatan antara mereka.

7) Jika konsep itu sudah disiapkan oleh eksportir, maka Importir tinggal mem-pelajarinya dan bila dapat menyetujui isinya kemudian ia menandatangani dan mengembalikannya kepada eksportir. Jika kedua belah pihak sudah menandatangani, satu original copy dipegang oleh oleh importir sebagai dokumen asli transaksi yang lazim disebut sebagai sale's confirmation. Kedua sale's confirmation copy yang asli ini mempunyai kekuatan hukum yang sama.

\section{b. Proses pembukaan L/C oleh impoter}

1) Importir meminta kepada bank devisa di negaranya untuk membuka sebuah Letter of Credit (L/C) sebagai dana yang dipersiapkan untuk melunasi hutangnya kepada eksportir, sejumlah yang disepakati dalam sale's contract sesuai dengan syarat-syarat pencairan yang disebut dalam sales contract, merujuk pada ketentuan dari The Uniform Customs and Practice of Documentary Letter of Credit yang diterbitkan oleh Kamar Dagang Internasional, Paris no. 500 atau UCP-DC-500. $\quad L / C$ yang dibuka adalah untuk dan atas nama eksportir atau orang atau badan usaha lain yang ditentukan eksportir, sesuai kesepakatan dalam sale contract. Bank devisa yang diminta eksportir membuka $L / C$ itu disebut opening bank. Bank inilah yang bertanggung jawab melakukan pembayaran atas
$L / C$ itu kepada eksportir penerima $L / C$. Importir yang meminta pembukaan $L / C$ disebut applicant.

2) Opening bank setelah menyelesaikan jaminan dana $L / C$ dengan importir, melakukan pembukaan $L / C$ melalui bank korespondennya di negara eksportir. Pembukaan $L / C$ dilakukan dengan surat, kawat, teleks, faksimile, atau media elektronik lainnya yang sah. Penegasan pembukaan $L / C$ dalam bentuk tertulis itu disebut $L / C$ confirmation yang diteruskan oleh opening bank kepada bank korespondennya di negara eksporter untuk disampaikan kepada penerima, yaitu eksportir yang disebut dalam surat itu. Bank koresponden yang diminta opening bank untuk menyampaikan amanat pembukaan $L / C$ disebut advising bank.

3) Advising bank setelah meneliti keabsahan amanat pembukaan $L / C$ yang diterimanya dari opening bank meneruskan amanat pembukaan $L / C$ itu kepada eksportir yang berhak menerima dengan surat pengantar dari advising bank. Surat pengantar itu disebut $L / C$ Advice, sedangkan eksportir penerima $L / C$ disebut sebagai beneficiary dari $L / C$ itu. Bila advising bank diminta dengan tertulis oleh opening bank untuk turut menjamin pembayaran atas $L / C$ tersebut, maka advising bank juga disebut sebagai confirming bank.

\section{c. Proses pengiriman barang (Cargo Shipment Process) oleh eksporter}

1) Eksportir setelah menerima $L / C$ confirmation yang sifatnya operatif (sah sebagai landasan pembayaran) kemudian memper-siapkan barang ready for export, melakukan booking 
kapal atau memesan ruangan/tempat kepada perusahaan pelayaran (shipping company) yang kapalnya akan berangkat ke pelabuhan tujuan yang dimaksud dalam sale's contract serta sesuai dengan waktu pengapalan (shipment date) yang disepakati dalam sale contract tersebut. Eksportir kemudian mengurus formalitas ekspor seperti mengisi pemberitahuan ekspor barang, membayar Pajak Ekspor (PE) dan Pajak Ekspor Tambahan (PET) melalui advising bank, mengurus izin muat kepada Kantor Inspeksi Bea dan Cukai di pelabuhan muat. Setelah semua formalitas ekspor selesai, eksportir menyerahkan barang kepada perusahaan pelayaran (shipping company) untuk dimuat pada waktu yang disepakati.

2) Shipping company, setelah selesai melakukan pemuatan barang ke atas kapal, menyerahkan bukti penerimaan barang, bukti kontrak angkutan, dan bukti pemilikan barang dalam bentuk Bill of Lading (BL) atau transport documents lainnya kepada eksportir yang dalam pengangkutan ini disebut sebagai shipper.

3) Shipping company selanjutnya bertanggung jawab mengangkut muatan itu sampai ke pelabuhan tujuan, serta menyerahkannya dengan selamat dan utuh kepada penerima barang yang disebut dalam $B / L$ di pelabuhan tujuan (destination port) yang juga disebutkan dalam $B / L$ itu.

4) Importir selaku penerima barang (consignee), bila telah menerima dokumen-dokumen pengapalan (shipping document) dari opening bank, mengurus izin impor (import clearance) kepada pihak Bea Cukai di pelabuhan tujuan. Kemudian importir menghubungi agen pelayaran (shipping agent) di pelabuhan tujuan di negaranya untuk menerima muatan itu.

5) Shipping agent menyerahkan muatan kepada importir segera setelah pelunasan biayayang menjadi hak skipping agent berssmgkutan. Dengan ini maka selesailah proses penerimaan barang oleh importir.

\section{d. Negosiasi Dokumen pengapalan (Shipping Documents Negotiation Process)}

1) Eksportir, setelah menerima Bill of Lading dari perusahaan pelayaran, menyiapkan semua dokumen pengapalan yang disyaratkan dalam $L / C$ seperti faktur, daftar pengepakan, sertifikat mutu, Certificate of Origin atau Surat Keterangan negara Asal (SKA) dan lain sebagainya seperti wesel (draft) serta surat pengantar negosiasi dokumen secara lengkap dan cermat.Semua dokumen pengapalan itu diserahkan eksportir kepada negotiating bank yang ditentukan dalam $L / C$ untuk memperoleh pembayaran (payment).

2) Negotiating bank meneliti semua dokumen pengapalan yang diminta dalam syarat-syarat $L / C$. Bila semuanya cocok baik jumlah, jenis, maupun uraian sebagaimana yang dituntut oleh $L / C$, maka negotiating bank akan membayarkan jumlah yang ditagih oleh eksportir dari dana $L / C$ yang tersedia. Perlu diketahui bahwa kapan $L / C$ bisa dicairkan, itu tergantung kepada kesepakatan antara eksporter dan impoter yang telah dituangkan dalam kontrak dagang ekspor. Begitu juga jenis $L / C$ dan 
waktu pencairan, semua harus sudah disepakati dan dimuat dalam kontrak.

3) Negotiating bank meneruskan dokumen pengapalan yang sudah dilunasi itu kepada opening bank yang membuka $L / C$ bersangkutan sebagai penagihan kembali dari uang yang sudah dibayarkan oleh negotiating bank tersebut kepada eksportir.

4) Opening bank memeriksa dokumen pengapalan dan bila sudah sesuai dengan syarat-syarat $L / C$ yang dibuka maka opening bank kemudian melunasi uang yang sudah dibayarkan oleh negotiating bank. Pembayaran pelunasan kembali ini disebut sebagai reimbursement.

5) Opening bank selanjutnya memberitahukan penerimaan dokumen pengapalan itu kepada importir. Importir akan mengambil dokumen pengapalan itu kepada opening bank dan menyelesaikan pelunasan dokumen pengapalan tersebut dengan opening bank bersangkutan. Setelah itu opening bank akan menyerahkan seluruh dokumen pengapalan itu kepada importir untuk digunakan saat menerima barang bersangkutan dari perusahaan pelayaran dan Bea Cukai setempat.

\section{Teori Pendukung}

\section{Standar Kontrak}

Menurut Mariam Darus, standar kontrak terbagi 2 yaitu umum dan khusus.

- Kontrak standar umum artinya kontrak yang isinya telah disiapkan lebih dahulu oleh pihak-pihak yang berkepentingan. Misalnya antara eksporter dan impoter.
- Kontrak standar khusus, artinya kontrak standar yang ditetapkan pemerintah baik adanya dan berlakunya untuk para pihak ditetapkan sepihak oleh pemerintah. Biasanya ini berlaku untuk mereka yang ingin melakukan transaksi untuk suatu

Pada dasarnya orang bebas untuk membuat bentuk-bentuk kontraknya sendiri, oleh karena kontrak adalah dokumen tertulis yang menuangkan kesepakatan yang telah dibuat oleh mereka, sehingga bagaimana bentuk dan apa isinya, adalah sepenuhnya tergantung kepada mereka sendiri. Jika sudah diperjanjikan tertulis, maka menurut pasal 1338 KUHP, itu akan menjadi hukum yang mengikat kedua belah pihak.

Terdapat beberapa hal di dalam ketentuan peraturan perundangundangan, yakni pasal 1320 KUHPer, yang mensyaratkan bahwa suatu kontrak akan sah jika:

1. ada kesepakatan dari para pihak untuk mengikatkan diri. Sepakat maksudnya adalah bahwa para pihak yang mengadakan perjanjian itu harus bersepakat, setuju untuk seia sekata mengenai segala sesuatu yang diperjanjikan. Kata sepakat ini harus diberikan secara bebas, artinya tidak ada pengaruh dipihak ketiga dan tidak ada gangguan.

2. para pihak yang membuat perjanjian memiliki kecakapan dalam membuat perjanjian, artinya mereka mempunyai wewenang untuk membuat perjanjian atau mengadakan hubungan hukum. Pada asasnya setiap orang yang 
sudah dewasa dan sehat pikirannya adalah cakap menurut hukum.

3. Suatu hal tertentu Suatu hal tertentu merupakan pokok perjanjian.Artinya apa yang diperjanjikan harus merupakan suatu obyek yang jelas, tidak terselubung. Syarat ini diperlukan untuk dapat menentukan kewajiban para pihak jika terjadi perselisihan. Pasal 1338 KUH Perdata menyatakan bahwa suatu perjanjian harus mempunyai sebagai suatu pokok yang paling sedikit ditetapkan jenisnya.

4. Sebab yang halal. Artinya perjanjian antara kedua belah pihak adalah sesuatu yang tidak melanggar ketentuan perundangundangan yang berlaku. Menurut Pasal 1337 KUH Perdata, sebab yang tidak halal ialah jika ia dilarang oleh Undang Undang, bertentangan dengan tata susila atau ketertiban. Menurut Pasal 1335 KUHPerdata, perjanjian tanpa sebab yang palsu atau dilarang tidak mempunyai kekuatan atau batal demi hukum.

Berdasarkan Pasal 1320 jo 1338 ayat (1) BW/ KUHPerdata dikenal adanya asas konsensual, yang dimaksud adalah bahwa perjanjian/kontrak lahir pada saat terjadinya konsensus/sepakat dari para pihak pembuat kontrak terhadap obyek yang diperjanjikan.

Pada umumnya perjanjian yang diatur dalam BW bersifat konsensual. Sedang yang dimaksud konsensus/ sepakat adalah perte- muan kehendak atau persesuaian kehendak antara para pihak di dalam kontrak. Seorang dikatakan memberikan persetujuan/kesepakatan (toestemming), jika ia memang menghendaki apa yang disepakati.

Mariam Darus Badrulzaman juga melukiskan pengertian sepakat sebagai pernyataan kehendak yang disetujui (overeenstemende wilsverklaring) antar pihakpihak. Pernyataan pihak yang menawarkan dinamakan tawaran (offerte). Pernyataan pihak yang menerima penawaran dinamakan akseptasi (acceptatie). Jadi pertemuan kehendak dari pihak yang menawarkan dan kehendak dari pihak yang akeptasi itulah yang disebut sepakat dan itu yang menimbulkan/melahirkan kontrak/perjanjian.

Untuk kontrak dagang internasional, terdapat Konvensi PPB mengenai Kontrak jual beli barang secara internasional, (UN CONVENTION ON CONTRACTS FOR THE INTERNATIONAL SALE OF GOODS, 1980), yang antara lain mengatur tentang

Ps. 1 : Konvensi ini akan berlaku terhadap kontrak -kontrak jual beli barang antara para pihak yang tempat usahanya berada di negara yang berlainan:

a. bilamana negara-negara tersebut adalah negara peserta; atau

b. bilamana peraturan hukum perdata internasional menyebabkan berlakunya 
hukum dari suatu negara peserta.

Ps.2 : Konvensi ini tidak berlaku terhadap jual-beli :

a. Barang yang dibeli untuk keperluan pribadi, keluarga atau rumah tangga, kecuali penjual, setiap saat sebelum atau pada waktu penyelesaian kontrak, tidak mengetahui atau tidak seharusnya mengetahui bahwa barang yang dibeli adalah untuk keperluan tersebut di atas

b. Melalui lelang

c. Melalui eksekusi atau karena wewenang hukum

d. Obligasi, saham, investment securities, kertas berharga, atau uang

e. Kapal, kendaraan terapung, hovercraft atau pesawat terbang

f. Listrik

Kontrak Dagang Ekspor merupakan dokumen tertulis hasil kesepakatan antara eksportir dan impotir, yang di dalamnya berisi:

1. Nama dan tanda tangan pihakpihak yang membuat kontrak.

2. Subjek kontrak

3. Lingkup kontrak

4. Kewajiban dan tanggung jawab

6. Pembatalan kontrak

7. Cara penyelesaian jika antara kedua belah pihak terjadi sengketa.

\section{Kontrak Dagang Ekspor dibutuhkan} karena :

1. Resiko timbulnya sengketa

Terjadinya sengketa dalam pelaksanaan ekspor impor sangat dimungkinkan, oleh karena pihakpihak yang bertransaksi adalah mereka yang berasal dari negara berbeda, dengan berbagai perbedaan yang ada.

2. Resiko kehilangan dan kerusakan Pengiriman barang dari suatu negara ke negara lain jelas meiliki resiko tinggi, baik melalui kapal laut maupun kapal udara. Melalui laut, jarak tempuh bisa berhari-hari, bahkan bisa sampai sebulan, di tengah-tengah gelombang samudera yang memiliki resiko tinggi, termasuk juga dari adanya badai maupun kejahatan para bajak laut.

3. Resiko perbedaan mata uang

Kondisi keuangan suatu negara dengan negara lain juga saling berbeda, sehingga selalu ada fluktuasi nilai mata uang. Hal ini menyebabkan nilai ekspor dalam setiap transaksi akan beresiko mengalami perbedaan pada saat kesepakatan dicapai dengan saat pembayaran dilakukan.

4. Resiko akibat perbedaan bahasa

Perbedaan bahasa yang digunakan oleh para pihak yang berasal dari negara berbeda, memiliki resiko terjadinya perbedaan dalam memahami isi kesepatan, sehingga akan berakibat perbedaab pula dalam pelaksanaannya.

5. Resiko perubahan sosial politik

Kebijakan dan kondisi keamanan sosial di suatu negaa juga bisa 
menjadi penghalang kelancaran pelaksanaan suatu transaksi, karena bisa saja setelah dicapai kesepakatan antara kedua belah pihak, tetapi kemudian terjadi hal-hal yang menyebabkan transaksi itu gagal atau tidak bisa dilaksanakan. Misalnya adalah terjadi pemberontakan, kudeta, keurusuhan sosial, perubahan kebijakan ekspor, dan lain-lain.

\section{Definisi Operasional, Variabel dan indikator yang digunakan}

1. Definisi operasional

Dalam rangka mendapatkan persamaan persepsi mengenai variabel yang dibahas, maka perlu diberikan definisi operasional dan variabel sebagai berikut:

a. Kontrak dagang ekspor adalah dokumen tertulis yang menyebutkan berbagai hal yang sudah disepakati oleh eksporter dan impoter dalam suatu transaksi, yakni tentang hak dan kewajiban kedua belah.

b. Transaksi ekspor yang menggunakan Kontrak Dagang akan efektif jika para pihak memahami benar apa yang sudah disepakati, diperjanjikan dan dituangkan dalam dokumen tertulis itu.

C. Bagaimana realisasi ekspor bisa dijamin lancar, adalah jika kedua belah pihak sepenuhnya menjalankan apa yang sudah dituangkan dalam dokumen Kontrak Dagang Ekspor, sehingga dapat dihindari kemungkinan timbulnya wanprestasi, penyimpangan, maupun sengketa.
2. Variabel

Variabel yang digunakan dalam penulisan ini adalah:

a. Isi dokumen kontrak dagang ekspor

b. Pemahaman para pihak atas hak dan kewajiban masing-masing

c. Kemampuan para pihak untuk me-laksanakannya secara baik maupun untuk menegakkannya jika terjadi penyimpangan dalam pelaksanaan.

\section{TEMUAN DAN PEMBAHASAN}

\section{A. Pengungkapan masalah}

Kontrak dagang, utamanya adalah berfungsi sebagai pelindung atas hak dan kewajiban eksportir dan importer, mengingat kedua belah pihak adalah berasal dari negara-negara yang masing-masing memiliki banyak perbedaan. Oleh karena itu, melalui kontrak dagang diharapkan fungsifungsi berikut dapat terjamin, yakni:

- jaminan pencapaian tujuan bersama

- Penampungan pokok kesepahaman bersama

- Untuk melaksanakan hak \& kewajiban yang telah disepakati terhadap jasa \& barang agar tidak terjadi pelanggaran.

- Alat kontrol pemenuhan hak dan kewajiban para pihak 
- Landasan hukum penyelesaian sengketa

- Alat bukti tatkala diuji di pengadilan

\section{Manfaat kontrak dagang ekspor}

Di samping memberikan kepastian atas produk/jasa yang akan diperjualbelikan, kontrak dagang juga bermanfaat bagi kedua belah pihak, oleh karena:

- Memberikan kepastian atas status order

- Memberikan kepastian atas prosedur pembayaran

- Mengurangi resiko kerugian

- Memberikan kepastian tentang resiko yang ditanggung para pihak

- Memberikan kepastian hukum pemenuhan hak dan kewajiban

\section{Isi Kontrak Dagang}

Berikut adalah isi kontrak dagang ekspor yang harus dicermati:

1. Number of the contract

2. Company name, address, phone and fax number, email address of the related party

3. Conformity content of the contract

4. Kind of goods, quantity, quality and specification

5. Unit price and total price

6. Incoterms

7. Shipment terms and conditions (direct/transhipment)

8. Payment systems

9. Special or other conditions (if any)

10. References of the contract
11. Free flag vessel, free vessel age

12. Equal treatment (Penalty for late shipment/late payment)

13. Completness of the goods document

14. Signatures of the contract

15. Dispute settlement

16. Attachment (shipment, force majeur, inspection, quality, packing \&marketing, insurance \& freight, payment, claim)

\section{Negosiasi isi kontrak dagang}

Point-poin yang perlu diperhatikan dalam menyusun kontrak dagang adalah:

1. Kind of goods, quantity, quality and specification

2. Unit price and Total price

3. Packaging of goods or merchandise

4. Incoterms

5. Shipment terms and conditions (direct/transhipment)

6. Payment systems

7. Special or other conditions (if any)

8. References of the contract

9. Dispute settlement

10. Free flag vessel, free vessel age

11. Equal treatment (Penalty for late shipment/late payment)

12. Completly of the goods document

\section{Menyusun Kontrak Dagang Ekspor}

Untuk menghindari kesalahpahaman, maka dalam memyusun kontrak dagang, harus memperhatikan:

1. Penulisan yang tegas dan jelas 
2. Persyaratan yang lengkap dalam perencanaan suatu kontrak

3. Perhatikan contoh kontrak dan formatnya, walaupun, tidak sematamata mencontoh secara keseluruhan.

4. Buat suatu kontrak sesuai dengan format standar

5 Mengetahui aspek-aspek legalitas

\section{BAB IV \\ PENUTUP}

\section{A. Kesimpulan}

Kontrak Dagang adalah instrumen penting dalam kegiatan ekspor impor karena merupakan landasan pijak bagi kedua belah pihak, yakni penjual (ekspoter) dan pembeli (impoter), untuk melaksanakan sekaligus menuntut hak-haknya. Kontrak dagang ekspor bisa dibuat dalam bentuk yang sederhana maupun yang rumit. Yang terpenting dalam Kontrak Dagang adalah adanya kesepakatan antara kedua belah pihak, sehingga bagaimana bentuk ataupun isi yang diperjanjikan diserahkan sepenuhnya kepada kesepakatan mereka, asalkan dianggap bisa melindungi kepentingan mereka masing-masing.

\section{B. Rekomendasi}

1) Mengingat bahwa dalam era globalisasi perdagangan bebas sekarang ini intensitas transaksi dagang antara UKM Indonesia dengan mitra dagangnya akan semakin meningkat, maka sudah selayaknya kepada mereka dilakukan upaya-upaya untuk meningkatkan pengetahuan mereka dalam masalah pembuatan kontrak dagang ekspor dan juga bagaimana mereka bisa menyusun suatu kontak yang memenuhi kaedahkaedah hukum dan memberi jaminan perlindungan kepada mereka untuk mendapatkan hakhaknya serta untuk mau melaksanakan kewajibannya sesuai dengan kesepakatan bersama dengan importer.

2) Di samping masalah peningkatan SDM UKM eksporter dalam masalah kontrak dagang, lembagalembaga advokasi dalam penyelesaian permasalahan perdagangan kiranya juga perlu terus ditingkatkan.

Jakarta, 31 Oktober 2018

\section{DAFTAR PUSTAKA}

Amir, MS 1999.Ekspor impor Teori dan Penerapana,Jakarta : PT. Pustaka Binaan Pressindo

2002.Kontrak Dagang

Ekspor,Jakarta : PT. Pustaka Binaan

Pressindo

Hari Murti,dan Wahyu Agung Setyo. 2009. Panduan Magang Kerja dan Penulisan Tugas Akhir D-3 Bisnis Internasional. Fakultas Ekonomi Universitas Sebelas Maret Surakarta

PPEI, BPEN \& DEPPERINDAG, 2009. Modul Penunjang Praktek DIII Bisnis Internasional. PPEI : Jakarta

Subekti, "Aneka Perjanjian" cetakan keenam, Bandung; alumni 